\title{
Influence of themo-mechanical treatments and microstructural state on the fatigue behaviour of a weld seam: case of API X60 steel
}

\author{
Mohammed Achoui, Fethi Sebaa \\ University of Tlemcen, Ingeniery of Mechanical Systems and Materials Laboratory, Tlemcen, Algeria \\ achoumedi@yahoo.fr,bttp://orcid.org/0000-0001-2345-6789 \\ sebaafeth@yahoo.fr, bttps://orcid.org/0000-0001-5630-7819
}

Benattou Bouchouicha

University Djillali Liabes of Sidi Bel Abbes, Reactive Materials and Systems Laboratory (LMSR), Sidi Bel Abbes, Algeria benattou_b@yahoo.fr, bttps://orcid.org/0000-0002-6051-5108

\begin{abstract}
The aim of this work is the study of the fatigue behaviour of API X60 steel and the influence of thermal and mechanical treatments. The evaluation of the integrity and safety of welded structures dictates the approach taken in this research. The microstructural observations on the different zones of the weld seam indicates that the variation of heterogeneous structure is a progressive destruction of the strips of lamination which cause a new phase leading to a drop in the mechanical properties requiring treatment after welding. The fatigue cracking rate diverges beyond the threshold of $\Delta \mathrm{K}$, but no deviation of the crack from its propagation axis was noticed, which confirms the correct choice of filler metal over that of the base metal with an overmatching $\mathrm{M}=1.1$, and the treatments applied to the structure. This fatigue cracking rate transversal to the welding direction initially presents an aspect similar to that of BM but registers a delay as soon as the crack tip enters the second zone (HAZ) then it progresses rapidly. This evolution is characterized by a disturbance due to the repeated change of microstructure.
\end{abstract}

KEYWORDS. Fatigue crack; Thermal-mechanical treatment; microstructure of welded joints; crack propagation; mechanical properties of API X60 steel; chemical composition.

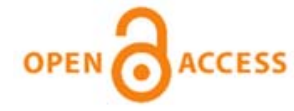

Citation: Achoui, M., Sebaa, F., F Bouchouicha, B., Influence of themomechanical treatments and microstructural state on the fatigue behaviour of a weld seam: case of API X60 steel, Frattura ed Integrità Strutturale, 58 (2021) 365-375.

Received: 28.06 .2021

Accepted: 19.09 .2021

Published: 01.10.2021

Copyright: (C) 2021 This is an open access article under the terms of the CCBY 4.0, which permits unrestricted use, distribution, and reproduction in any medium, provided the original author and source are credited.

\section{INTRODUCTION}

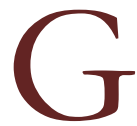
enerally, industrial structures, consist of elements assembled by welding, show geometric discontinuities near which areas of stress concentration are formed. These areas are the prime sites for the initiation and propagation of fatigue cracks which are the real causes for the damage to these structures. When designing mechanical structures or pipelines, it is essential to have tools capable of predicting their fatigue resistance under conditions close to actual operation. 
Cracks in weld joints, base metal, overloads due to vibratory movements, corrosion, maintenance and rehabilitation work can also lead to nicks or scratches and indentations in structures [1-3]. Rupture prevention is built on an in-depth knowledge based on tangible facts and on data to support them. It starts with the engineering and design of the pipelines, during the exploitation and manufacturing of the structures. These latter will continue to deteriorate over time; they will be subjected to variable environmental conditions and to external events that their manufacturers could not, always, predict.

Several studies have discussed the factors affecting the life of welded structures, including heterogeneity, welding conditions and of course the filler metal [4-5]. The right choice of this latter improves, considerably, fatigue resistance of structures [69]. The microstructure of the material has a considerable effect on the propagation behaviour of fatigue cracks in structures, which has become the center of attention of researches for many years.

These microstructural effects are associated with welding conditions especially the position of the weld seam according to the orientation of loads and stresses [10-11]. The thermal effect of the welding cycle gives microstructural heterogeneity in this zone (HAZ) made up of several subzones with different microstructures that can cause different behaviours [12-14]. A ferrite-bainitic microstructure offers better resistance to crack propagation in the welded zone than the martensitic or bainitic structures [15]. Indeed, a better combination of resistance and fatigue crack growth instead of rupture was observed for steel containing more than $70 \%$ of martensite and low carbon content.

This study deals with the influence of the thermal and mechanical treatment on the fatigue behaviour of a welded joint. This is a useful step in assessing the integrity and safety of welds. On the other hand, the microstructure and effects of reducing internal stresses using the advance fatigue crack ligament pre-compression method were also analysed.

\section{EXPERIMENTATION}

\section{Material presentation}

$\mathrm{O}$ ur study focuses on API X60 steel, used for the manufacturing of gas tanks (Liquefied petroleum gas LPG) and the construction of pipelines. Welding is performed by Submerged Arc Welding (SAW) with coated electrodes GMoSi. The basic chemical composition and mechanical properties of the two materials are given by Tab. 1 and 2 respectively.

\begin{tabular}{lccccccc}
\hline & $\mathrm{C} \%$ & $\mathrm{Mn} \%$ & $\mathrm{P} \%$ & $\mathrm{Si} \%$ & $\mathrm{~S} \%$ & $\mathrm{~V} \%$ & $\mathrm{Mo} \%$ \\
\hline & 0.22 & 1.4 & 0.03 & - & 0.03 & $<0.01$ & - \\
Base Material (BM) API X60 & 0.1 & 1.15 & - & 0.6 & - & - & 0.52 \\
\hline
\end{tabular}

Table 1: Chemical Composition of BM and FM (WM).

\begin{tabular}{lccccc}
\hline & Re (MPa) & Rm (MPa) & A \% & k & $\mathrm{n}$ \\
\hline Base Material (BM) API X60 & 414 & 517 & 25 & 578 & 0.1 \\
\hline Filler Metal FM GMoSi & 460 & 560 & 22 & 836 & 0.3 \\
\hline
\end{tabular}

Table 2: Mechanical properties du BM et FM (WM).

\section{Micrographic examinations}

Micrographic examinations on polished cuts $(1 \mu \mathrm{m})$ then attacked with $3 \%$ Nital, were carried out using a microscope. The aim is to observe the structures in very localized areas on the surface and transversal perpendicular to the welded seam in the three areas illustrated by Fig. 1

The transformations that the HAZ undergoes cannot be simulated to the heat treatments applied to steels. Indeed, after a welding operation, there is the appearance of bainite and intergranular ferrite in the junction zone and the transformation zones.

- Zone Z1 (BM): The observation shows the presence of ferrite and ferrite-perlite (an alternating structure of ferrite and perlite characteristic of bands of lamination (Fig. 2 a). 
- Zone (Z3) FM (WM): In the last pass, the arrangements of the ferritic areas and of the carburized constituents similar to ferrite present a marked arrangement linked to solidification. Observation shows the presence of a dendritic structure with islets (ferrite-perlite) and fairly large grains (Fig. 2b).

- Zone HAZ: This zone presents a variation of heterogeneous structure and a progressive destruction of the bands of lamination (Fig. 2 c). In the area near the fusion line, an overheated structure appears with a particular aspect and disposition of the ferrite. We notice the presence of a new phase which is the acicular ferrite (in the form of needles).

This microstructure presents islets of slatted bainite separated by ferrite and has good mechanical properties. Recent works [16-17] practically detect similar observations.

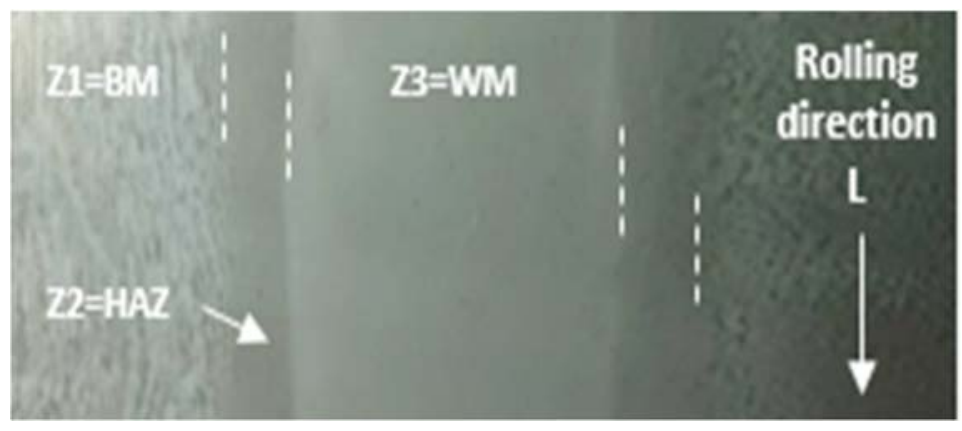

Figure 1: Polished cuts Orientation for micrographic exams.

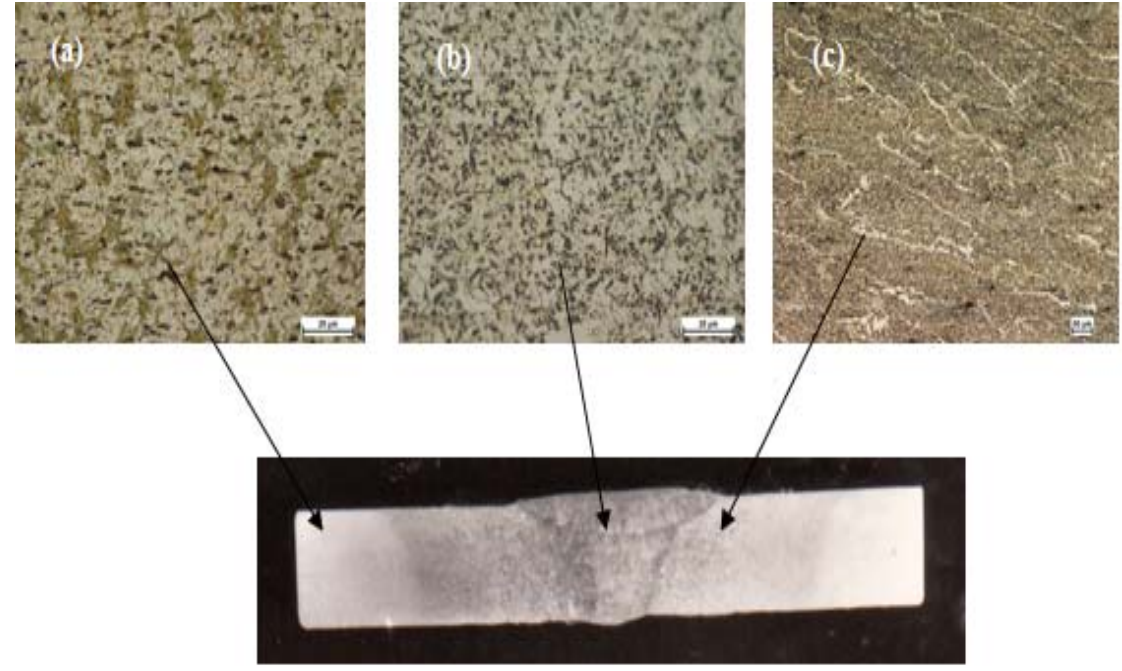

Figure 2: The Structure of the three zones with different magnifications: a - BM, b - FM (or WM), c - HAZ.

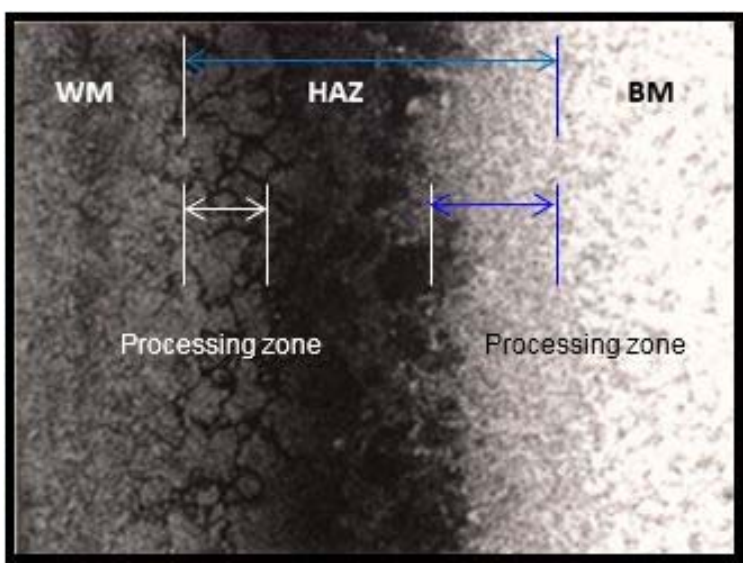

Figure 3: border junction between the three zones. 
The small, punctual "brown spots" distributed over the entire micrograph are localized chemical attacks. Fig. 3 shows the border junction between the three zones.

\section{FATIGUE CRACKING}

\section{Test conditions and instrumentation}

he cracking tests were carried out on $07 \mathrm{~mm}$ thick CT 50 test specimens compliant to the ASTM-E-647 standard. The tests were carried out in ambient air and for the same value of load ratio $\mathrm{R}=0.1$, and we used 3 test tubes for each case studied. The sampling of the test tubes was done according to Fig. 4.

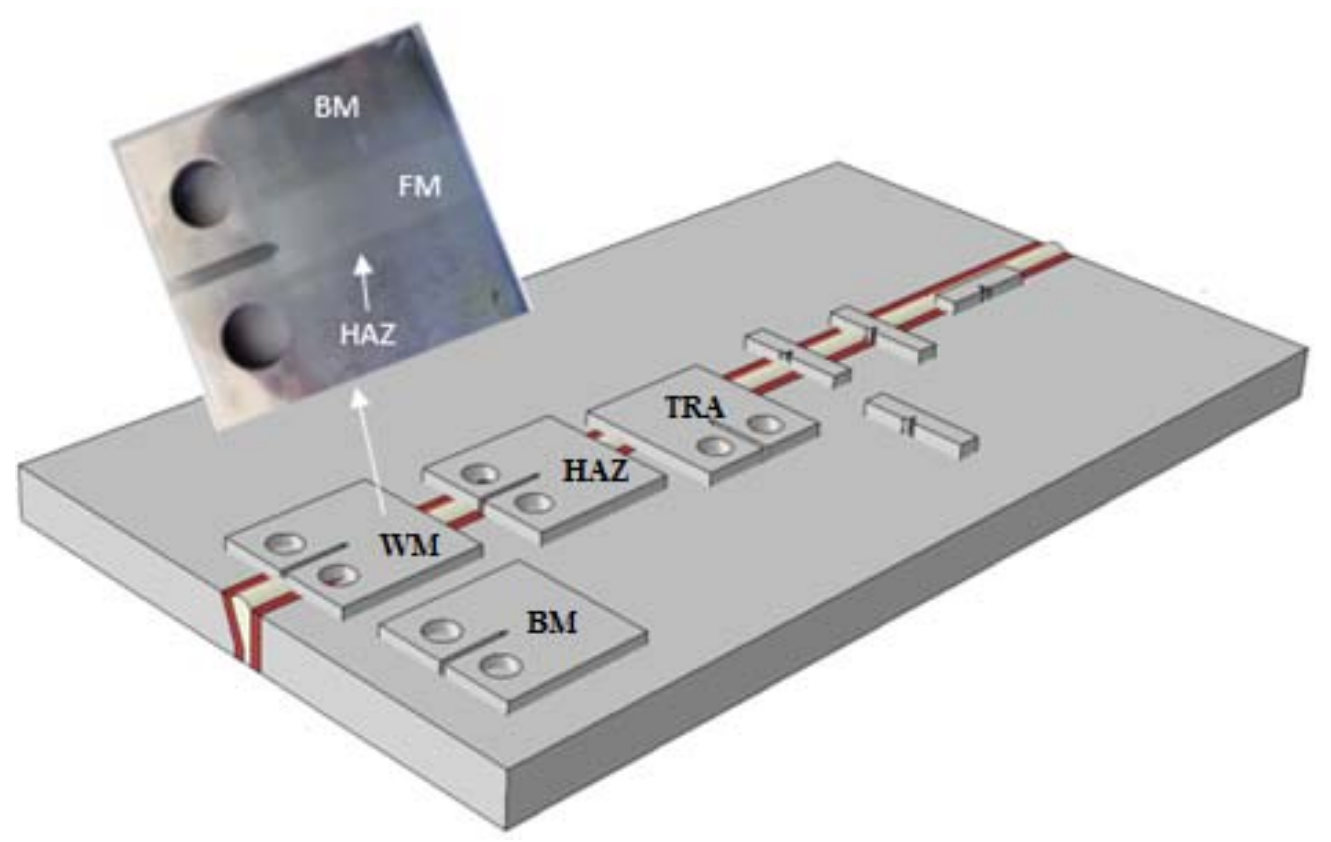

Figure 4: schematic representation of the sampling process.

\section{Calculation method of the cracking rate}

The smoothing of the curves is based on an incremental polynomial method that uses the smoothing of a series of successive points by a polynomial whose growth is monotonic in this interval [18]. The equation of the smoothed curve is of the form:

$$
a_{1}=b_{0}+b_{1}\left(\frac{N_{1}-C_{1}}{C_{2}}\right)+b_{2}\left(\frac{N_{1}-C_{1}}{C_{2}}\right)^{2}
$$

$\mathrm{b}_{0}, \mathrm{~b}_{1}$ et $\mathrm{b}_{2}$ : Regression parameters determined by the least square's method in an interval of seven points. Parameters C1 and $\mathrm{C} 2$ are used to normalize the data.

$$
\begin{aligned}
& C_{1}=\frac{1}{2}\left(N_{1-3}+N_{1+3}\right) \\
& C_{2}=\frac{1}{2}\left(N_{1+3}-N_{1-3}\right)
\end{aligned}
$$

The cracking rate at point $a_{i}$ is obtained from the derivative of the first expression. 


$$
\frac{d a}{d N}=\frac{b_{1}}{C_{2}}+2 b_{2}\left(\frac{N_{1}-C_{1}}{C_{2}^{2}}\right)
$$

\section{Elimination of residual stresses by local pre-compression}

During a fatigue cracking test on a weld seam, it is noted that the propagation of the fatigue crack is disturbed by the existing residual stress field. To remedy this problem, we used the local pre-compression method to limit the plastic deformation to a few percentages of the thickness in order to modify the progression of the crack. Fig. 5 schematically shows the principle of the method with the dimensions of the punches to be used. Fig. 6 represents the photo taken on the studied test tubes. The applied pressure and the penetration of the punch into the ligament are given respectively by relations (5) and (6):

$$
p=0.4 \cdot \operatorname{Re} \cdot B^{2}
$$

with:

Re: elastic limit of the material $(\mathrm{MPa})$

B: test tubes thickness (mm)

$$
T=0.5 \% B \quad \text { (totalised on both sides) }
$$
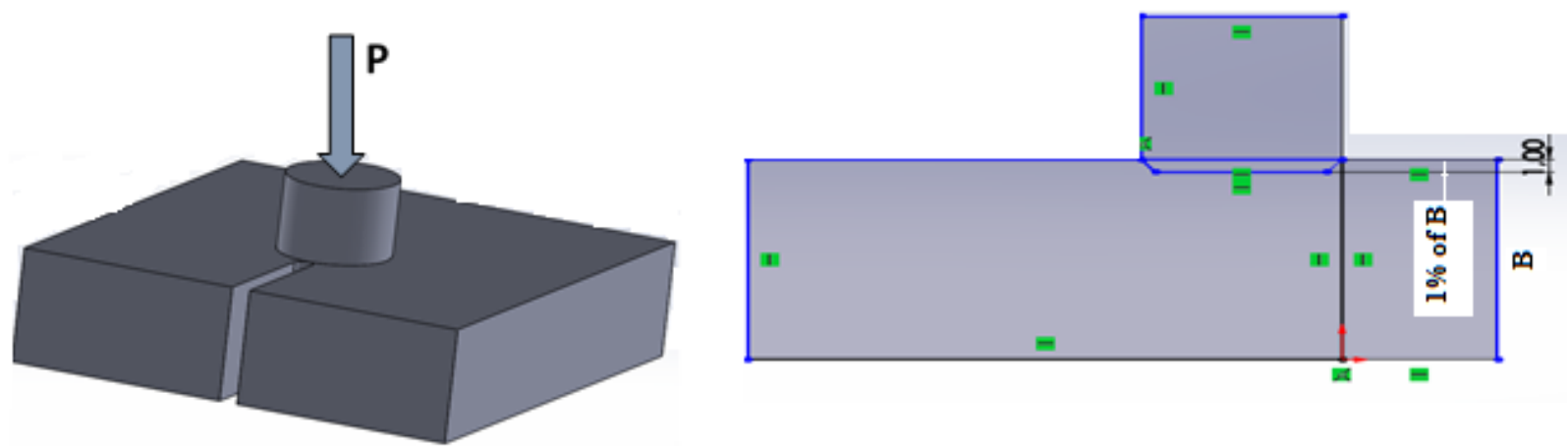

Figure 5: pre-compression method principal.

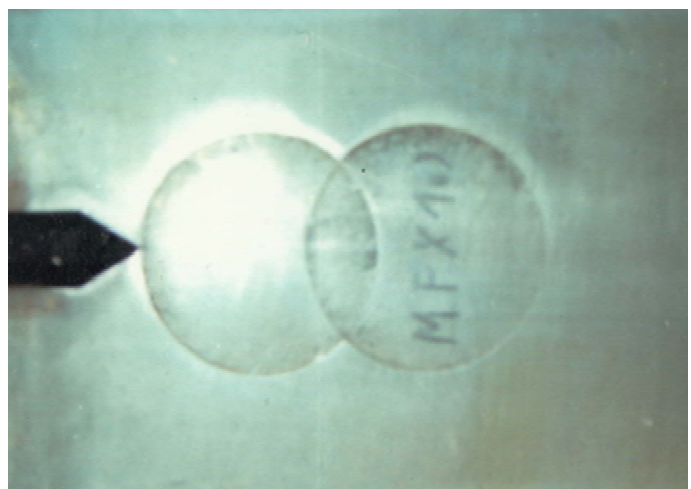

Figure 6: pre-compressed ligament.

\section{Crack's advance ligament treatment}

This operation went through two important phases, a preheating before the welding operation and a stress relieving annealing consisting of a slow lowering of the temperature. This treatment must guarantee perfect safety and reliability at the weld level depending on the thicknesses and the quality of the material while reducing internal stresses. In fact, this treatment was carried out in an oven at a maximum temperature of $580{ }^{\circ} \mathrm{C}$ for 2 hours, followed by a slow cooling to $320{ }^{\circ} \mathrm{C}$, then an exposure to a temperature below $200^{\circ} \mathrm{C}$, all the process took place at a temperature below AC1. Other techniques and procedures are also used [19-20]. 


\section{RESULTS AND DISCUSSION}

\section{Study on the three zones}

he obtained results concern the different test tubes in the three zones (BM - FM - HAZ) represented by Fig. 4. Tab. 3 encompasses the values of $\mathrm{C}$ and $\mathrm{m}$ of the PARIS law (formula 7) of the explored domain exhibiting an almost straight appearance.

$$
\frac{d a}{d N}=C(\Delta K)^{m}
$$

\begin{tabular}{ccc}
\hline Designation & \multicolumn{1}{c}{ Paris law } & $\Delta \mathrm{K}$ \\
BM & $\mathrm{da} / \mathrm{dN}=1.25 \mathrm{e}^{-11} \Delta \mathrm{K}^{4.3}$ & 20 to $62 \mathrm{MPa} \sqrt{m}$ \\
FM (WM) & $\mathrm{da} / \mathrm{dN}=9.76 \mathrm{e}^{-12} \Delta \mathrm{K}^{4.6}$ & 28 to $64 \mathrm{MPa} \sqrt{ } m$ \\
HAZ & $\mathrm{da} / \mathrm{dN}=6.33 \mathrm{e}^{-12} \Delta \mathrm{K}^{5.8}$ & 18 to $66 \mathrm{MPa} \sqrt{m}$ \\
FM After TTH & $\mathrm{da} / \mathrm{dN}=6.53 \mathrm{e}^{-10} \Delta \mathrm{K}^{3.1}$ & 18 to $60 \mathrm{MPa} \sqrt{m}$ \\
Transversal seam & $\mathrm{da} / \mathrm{dN}=1.42 \mathrm{e}^{-14} \Delta \mathrm{K}^{6.2}$ & 17 to $65 \mathrm{MPa} \sqrt{m}$ \\
FM Before comp & $\mathrm{da} / \mathrm{dN}=6.77 \mathrm{e}^{-15} \Delta \mathrm{K}^{6}$ & 22 to $50 \mathrm{MPa} \sqrt{m}$ \\
\hline
\end{tabular}

Table 3: $\mathrm{C}$ and $\mathrm{m}$ values of Paris law in the different studied zones.

Fig. 7 represents the crack growth rate $\mathrm{d} / \mathrm{dN}$ compared to $\Delta \mathrm{K}$ of the 3 zones with a load ratio $\mathrm{R}=0.1$. The results show that for low rates of $\Delta \mathrm{K}$, the growth of fatigue cracks is similar. However, for values of $\Delta \mathrm{K}$ greater than $30 \mathrm{MPa} . \mathrm{V}_{\mathrm{m}}$, this crack growth becomes more important respectively in the FM and the HAZ.

- For the values of $\Delta K>50 \mathrm{MPa} . V_{\mathrm{m}}$, the cracking rate presents a significant difference $(15 \%)$ between the 3 cases, which means that:

- In this studied area, the cracking rate presents an almost similar rate in the three zones.

- Even if the speeds differ in the three zones, but no deviation of the crack from its axis of propagation has been noticed, contrary to certain authors [21-23] who have shown that beyond a certain value of $\Delta \mathrm{K}$ the cracking speed is usually accompanied by a deviation of the crack from its initial plane towards base metal. This confirms that the weld was seine and the choice of a filler metal over that of the base metal is adequate. Usually, the deviation is due to the difference in mechanical characteristics between the three zones; the crack moves from a harder microstructure to a softer one.

Fig. 8 represents the cracking speed $\mathrm{d} / \mathrm{dN}$ according to in the molten metal after relaxation by heat treatment with the aim of eliminating the internal stresses arising from the solidification of the cooled welded parts.

The results show that the crack growth is initiated at a lower level of $\Delta \mathrm{K}$ than the state without heat treatment. And even for larger values of $\Delta \mathrm{K}$, a decrease in this speed was recorded with a regular growth of the fatigue crack. This means the elimination of internal stresses caused by solidification after welding.

\section{Transversal welding position}

The variation $\mathrm{d} a / \mathrm{dN}$, in the plate containing a transversal weld joint, follows a pace similar to that of $\mathrm{BM}$, but records a delay as soon as the crack tip enters the second zone (HAZ) then it progresses rapidly with a slope m close of 7 . This evolution is characterized by a disturbance due to the repeated change of the microstructure. In addition, the weld seam had a higher resistance to crack growth than the base metal, especially in the low range $\Delta \mathrm{K}$. As the growing crack propagated through HAZ and FM this resistance dropped (Fig. 9). 


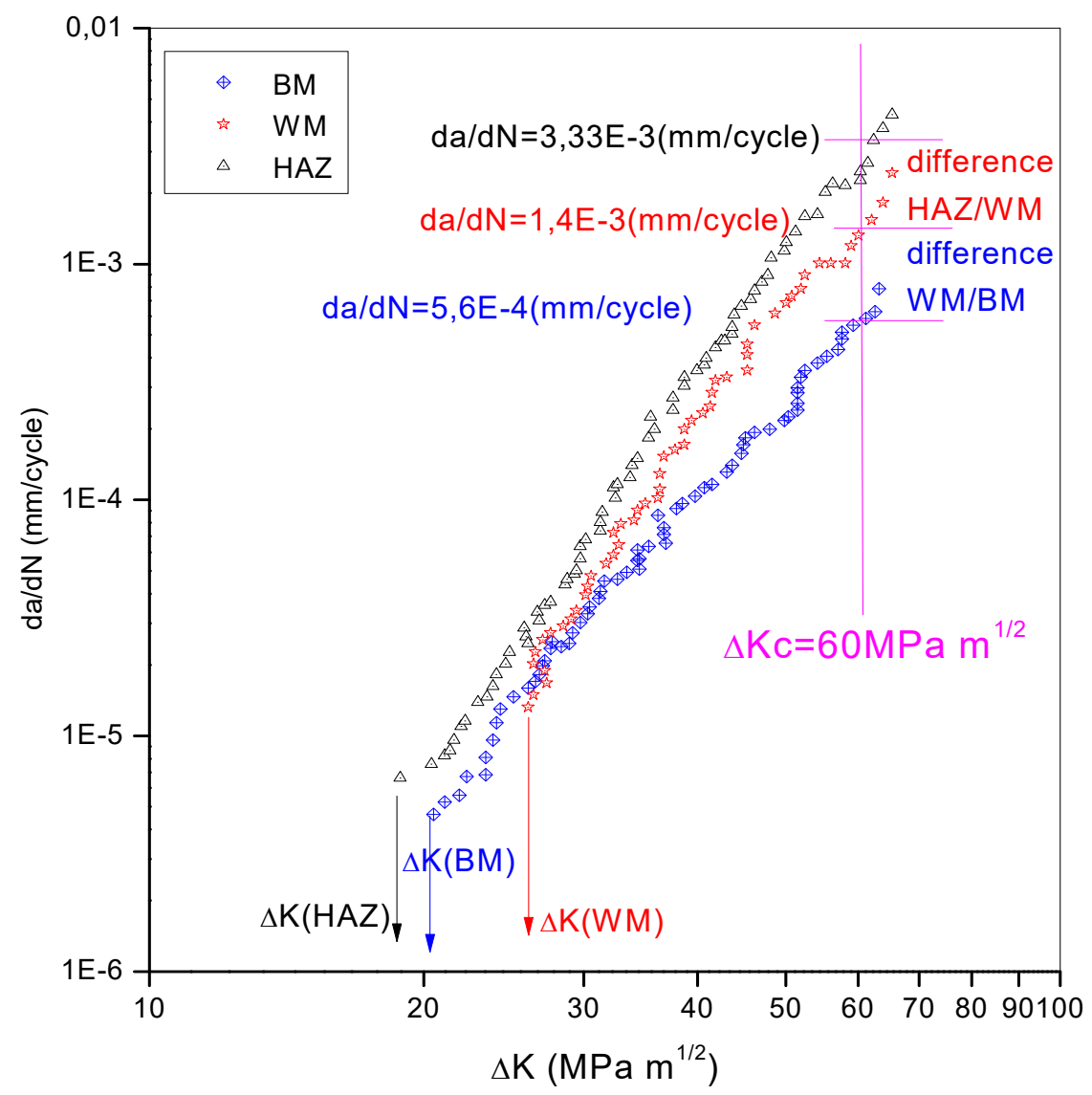

Figure 7: Crack speed evolution $\mathrm{da} / \mathrm{dN}=\mathrm{f}(\Delta \mathrm{K})$ in the three zones (BM, FM et HAZ).

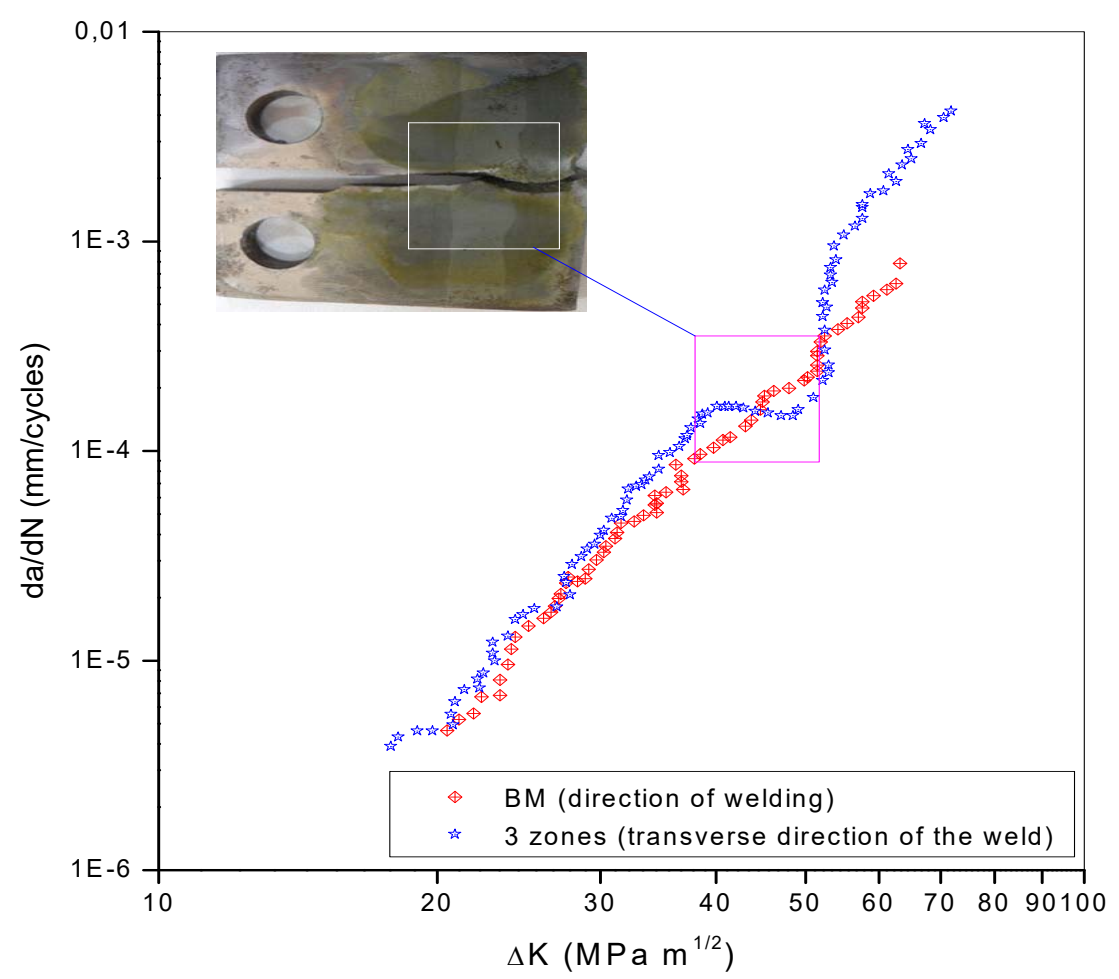

Figure 8: Comparison of the evolution of $\mathrm{da} / \mathrm{dN}=\mathrm{f}(\Delta \mathrm{K})$ before and after TTH. 


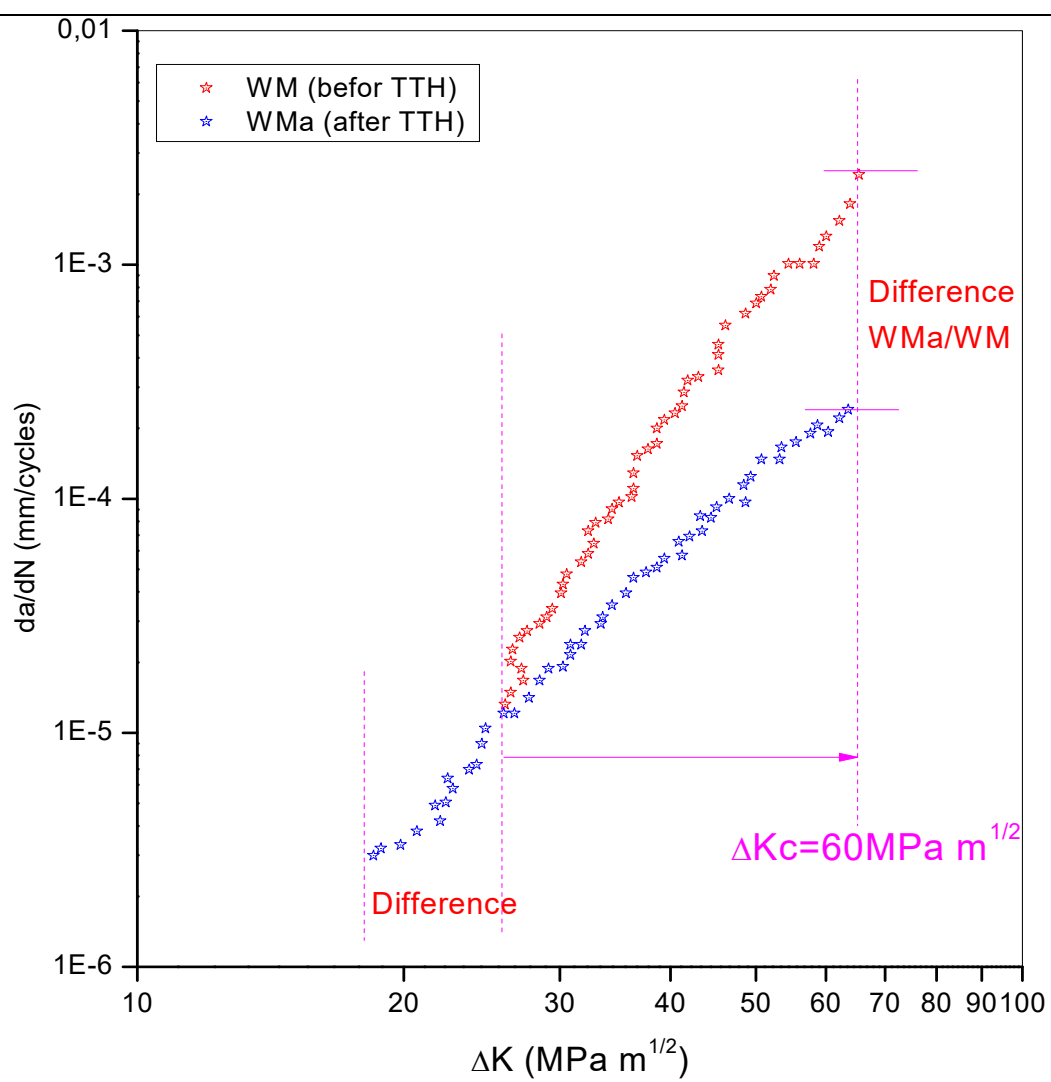

Figure 9: Comparison $d a / d N=\mathrm{f}(\Delta \mathrm{K})$ of $\mathrm{FM}$ longitudinal and transversal direction.

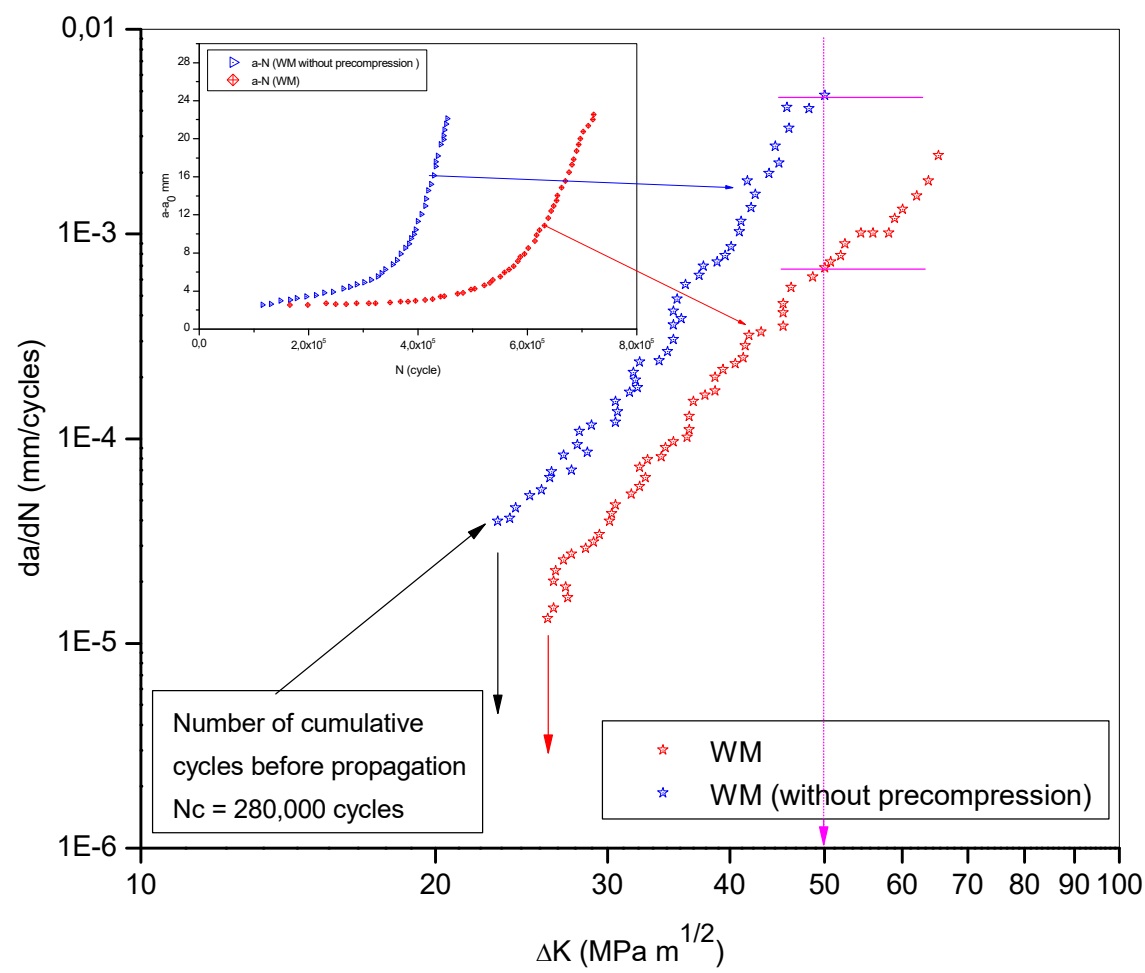

Figure 10: Comparison $d a / d N=\mathrm{f}(\Delta \mathrm{K})$ of FM With and without pre compression of the ligament. 


\section{Cracking on FM without pre compression}

Fig. 10 represents the evolution of the cracking speed before the relaxation of internal welding stresses at the pre-compression crack point. Indeed, this behaviour is in accordance with the residual stresses and the evolution of the closing of cracks. When the residual traction stresses act to fully open the crack, the test tube adopts a crack growth behaviour comparable to the base metal but with a large accumulation of number of fatigue cycles. The results show that the crack growth is very important after the delay recorded due to the closure by internal stresses and exhibits a practically constant deviation during the advance of the crack. The slope $m$ is increased and is comparable to the slope obtained in the HAZ. Other authors have drawn the same conclusions on X70 steel [23-25].

\section{CONCLUSION}

he influence of local treatment and the effects of reducing internal stresses on the fatigue behaviour of a weld joint have been dealt with in this study.

The following conclusions have been drawn:

(1) Appearance of bainite and intergranular ferrite in the junction zone and the transformation zones after a welding operation and before heat treatment.

- Far from the weld seam, the observation shows an alternating structure of ferrite and perlite characteristic of lamination strips. But on the seam and in the last pass, the observation shows the presence of a dendritic structure with isles (ferriteperlite) and fairly large grains. This phase can be assimilated to ferrite exhibiting a marked disposition linked to solidification.

- In the HAZ, we notice a gradual destruction of the lamination strips, resulting in a variation of heterogeneous structure. This justifies the obtained mechanical properties.

(2) Fatigue cracks show that for low rates of $\Delta \mathrm{K}$, crack growth is similar. But for $\Delta \mathrm{K}$ greater than $30 \mathrm{Mpa} . V_{\mathrm{m}}$, this crack growth becomes more important respectively in the FM and the HAZ. Approaching the third stage, the crack rate shows an important difference (15\%) between the 3 cases, which means that:

- After the initiation and exit from the wake of the residual stresses, the crack rate presents an almost similar pattern in the three zones.

- The adequate choice of the FM melted metal and the treatment of the crack tip ligament avoided deviating the crack from its propagation axis for the different configurations.

Contrary to certain authors [26] showing that beyond a certain value of $\Delta \mathrm{K}$, the crack rate is generally accompanied by a deviation of the crack from its initial plane towards the base metal.

(3) For the position of the transversal weld, the crack propagates perpendicular to the welding direction. We remark an evolution characterized by a disturbance due to the repeated change of microstructure. This case allows to have a similar appearance to that of BM but registers a delay as soon as the crack tip enters the second zone (HAZ) then it progresses rapidly. The mechanical properties drop as the crack propagates through the HAZ and FM.

\section{CONFLICT OF INTERESTS}

he authors declare that there is no conflict of interests regarding the publication of this paper.

\section{REFERENCES}

[1] Tirenifi, M., Chikh, B. O., Bouchouicha, B., and Bensari, A. (2019). Numerical comparison of cruciform weld and butt weld simulation and a study of fracture mechanics on two types of welds. Frattura e Integrita Strutturale, 13(48), pp. 357-369; DOI: 10.3221/IGF-ESIS.48.34. 
[2] Bensari, A., Ould Chikh, B., Bouchouicha, B., and Tirenifi M., (2019). Numerical Simulation of a Steel Weld Joint and Fracture Mechanics Study of a Compact Tension Specimen for Zones of Weld Joint. Frattura ed Integrità Strutturale, 13(47), pp. 17-29. DOI: 10.3221/IGF-ESIS.47.02.

[3] Arsic, M., Savic, Z., Sedmak, A., Bosnjak, S., and Sedmak, S. (2016). Experimental examination of fatigue life of welded joint with stress concentration. Frattura ed Integrità Strutturale, 10(36), pp. 27-35. DOI: 10.3221/IGF-ESIS.36.03 .

[4] Chaib, M., Slimane, A., Slimane, S. A., Ziadi, A., and Bouchouicha, B. (2021). Optimization of Ultimate Tensile Strength with DOE Approach for Application FSW Process in the Aluminum alloys AA6061-T651 and AA7075-T651. Frattura ed Integrità Strutturale, 15(57), pp. 169-181. DOI: 10.3221/IGF-ESIS.57.14.

[5] Slimane, A., Slimane, S., Kebdani, S., Chaib, M., Dahmane, S., Bouchouicha, B., Sardi, N. and Adjim, S. (2019). Parameters effects analysis of rotary ultrasonic machining on carbon fiber reinforced plastic (CFRP) composite using an interactive RSM Method. International Journal on Interactive Design and Manufacturing (IJIDeM), 13(2), pp. 521-529. DOI: $10.1007 /$ s12008-018-0518-0.

[6] Chattopadhyay, A., Glinka, G., El-Zein, M., Qian, J., and Formas, R. (2011). Stress analysis and fatigue of welded structures. Welding in the World, 55(7), pp. 2-21. DOI: 10.1007/BF03321326.

[7] Bouchouicha, B., Zemri, M., Zaim, A., and Chikh, B. O. (2015). Estimation of the energy of crack propagation in different zones of a welded joint by the local technique. International Journal of Fracture, 192(1), pp. 107-116. DOI 10.1007/s10704-015-9989-1.

[8] Deliou, A., and Bouchouicha, B. (2018). Fatigue crack propagation in welded joints X70. Frattura ed Integrità Strutturale, 12(46), pp. 306-318. DOI: 10.1007/BF02586155.

[9] Kainuma, S., and Mori, T. (2008). A study on fatigue crack initiation point of load-carrying fillet welded cruciform joints. International Journal of Fatigue, 30(9), pp. 1669-1677. DOI: 10.1016/j.ijfatigue.2007.11.003.

[10] Camagic, I., Vasic, N., Cirkovic, B., Burzic, Z., Sedmak, A., and Radovic, A. (2016). Influence of temperature and exploitation period on fatigue crack growth parameters in different regions of welded joints. Frattura ed Integrità Strutturale, 10(36), pp. 1-7. DOI: 10.3221/IGF-ESIS.36.0.

[11] Slimane, A., Kebdani, S., Bouchouicha, B., Benguediab, M., Slimane, S., Bahram, K., ... and Sardi, N. (2018). An interactive method for predicting industrial equipment defects. International Journal of Advanced Manufacturing Technology, 95(9-12), pp. 4341-4351. DOI: 10.1007/s00170-017-1416-5.

[12] Kaddour, B., Bouchouicha, B., Benguediab, M., and Slimane, A. (2018). Modeling and optimization of a cracked pipeline under pressure by an interactive method: design of experiments. International Journal on Interactive Design and Manufacturing (IJIDeM), 12(2), pp. 409-419. DOI 10.1007/s12008-017-0385-0.

[13] Wei, s., and Liu, X. (2018). High cycle fatigue assessment of steel load-carrying cruciform welded joints: an overview of recent results. Frattura Ed Integrità Strutturale, 12(46), pp. 94-101. DOI: 10.3221/IGF-ESIS.46.10.

[14] Ferro, P., Peron, M., Razavi, S. M. J., Berto, F., and Torgersen, J. (2017). The fatigue behavior of V-notches in presence of residual stresses: Recent developments and future outcomes. Frattura ed Integrità Strutturale, 11 (42), pp. 189-195. DOI: $10.3221 /$ IGF-ESIS.42.20.

[15] Slimane, A., Bouchouicha, B., Benguediab, M., and Slimane, S. A. (2015). Contribution to the Study of Fatigue and Rupture of Welded Structures in Carbon Steel-A48 AP: Experimental and Numerical Study. Transactions of the Indian Institute of Metals, 3(68), pp. 465-477. DOI: 10.1007/s12666-014-0477-5.

[16] Chrysanthopoulos, M.K. and Righiniotis, T.D. (2006). Fatigue reliability of welded steel structures, Journal of Constructional Steel Research, 62, 2006, pp.1199-1209. DOI: 10.1016/j.jcsr.2006.06.007.

[17] Bordbar, S., Alizadeh, M., and Hashemi, S. H. (2013). Effects of microstructure alteration on corrosion behavior of welded joint in API X70 pipeline steel. Materials and Design, 45, pp. 597-604. DOI: 10.1016/j.matdes.2012.09.051.

[18] Messabih, F. Z., and Bouchouicha, B. (2018). Coupling between Welding Conditions and Thermal Cycling for Identification of the Mechanical Heterogeneity of a Weld Joint. Periodica Polytechnica Mechanical Engineering, 62(3), pp. 226-232. DOI: 10.3311/PPme.12065.

[19] Alioua, A., Bouchouicha, B., Zemri, M., and Abdellatif, I. M. A. D. (2018). Effect of Filler Metal Mechanical Properties on Fatigue Behaviour Welded Joints. Transactions of the Indian Institute of Metals, 71(4), pp. 977-984.

DOI:10.1007/s12666-017-1231-6

[20] Alioua, A., Bouchouicha, B., Zemri, M., and Abdellatif, I. M. A. D. (2017). Fatigue behavior of mechanical structures welded with different filler metal. Advances in Materials Research, 6(3), 233. DOI: 10.12989/amr.2017.6.3.233.

[21] Slimane, S. A., Slimane, A., Guelailia, A., Boudjemai, A., Kebdani, S., Smahat, A., and Mouloud, D. (2021). Hypervelocity impact on honeycomb structure reinforced with bi-layer ceramic/aluminum facesheets used for spacecraft shielding. Mechanics of Advanced Materials and Structures, pp. 1-19. DOI: 10.1080/15376494.2021.1931991. 
[22] Tsay, L. W., Liu, C. C., Chao, Y. H., and Shieh, Y. H. (2001). Fatigue crack propagation in 2.25 Cr-1.0 Mo steel weldments in air and hydrogen. Materials Science and Engineering: A, 299(1-2), pp. 16-26. DOI: 10.1016/S09215093(00)01420-9.

[23] Akita, M., Nakajima, M., Tokaji, K., and Shimizu, T. (2006). Fatigue crack propagation of 444 stainless steel welded joints in air and in $3 \% \mathrm{NaCl}$ aqueous solution. Materials and design, 27(2), pp. 92-99. DOI: 10.1016/j.matdes.2004.10.004.

[24] Deliou, A., and Bouchouicha, B. (2018). Fatigue crack propagation in welded joints X70. Frattura ed Integrità Strutturale, 12(46), pp. 306-318. DOI: 10.3221/IGF-ESIS.46.28.

[25] Hwang, B., Kim, Y. G, Lee, S., Kim, Y. M., Kim, N. J. and Yoo, J. Y. (2005). Effective grain size and charpy impact properties of high-toughness X70 pipeline steels, Metallurgical and materials transactions A, 36A, pp. 2107-2114.

[26] Bahram, K., Bouchouicha, B., Benguediab, M. and Slimane, A. (2017). Admissibility of External Cracks in a Pipeline API X60 Using the SINTAP Procedure, Periodica Polytechnica Mechanical Engineering, 61(4), pp. 261-265.

DOI: 10.3311/PPme.1051612:409-419. 